\title{
What Is Humanity's Place in Nature, from an Objective (Biocentric) Point of View?
}

\author{
Michael J. Vandeman \\ Berkeley, California 94705, USA
}

Received: January 12, 2015 / Accepted: January 22, 2015 / Published: January 30, 2015

\begin{abstract}
Are humans part of nature? Clearly humans are, or they wouldn't be able to interact with it. The real question is what part are they? Most texts define an exotic species as one translocated by humans to an area where it had not previously existed. (This would seem to make humans, throughout most of their range, an exotic species, although this fact is never mentioned). But the effect that the species has on its new surroundings has little to do with how it got there, and more to do with its being a newcomer. What is a native species? It is basically one that has been around a long time, i.e., not a newcomer. The question is, how long? A length of time that makes sense is the length of time that it takes for the other species in the area to evolve to adapt to the newcomer-on the order of a million years. That would make humans native only to Africa, and everywhere else a rank newcomer (exotic species). This is not a value judgment, just biological fact, but maybe also a good indication of how we should behave: with restraint, with the manners of a guest.
\end{abstract}

Key words: Homo sapiens, native, exotic species, habitat.

"For hundreds of millennia, evolving humanity was a native species_-in Africa and Asia. ... The modern Races of Homo sapiens were a true alien species when they colonized the rest of the world, from Australia to the New World and finally the distant oceanic islands" [11].

"The behaviours animals use to avoid predators are both genetically based and learned. The genetic component is acquired through natural selection and so can only slowly be developed. This may account in part for the fact that most of the world's surviving large mammals live in Africa, for it was there that humanity evolved, and it was only there that animals had the time to acquire the genetically based behaviours that allowed them to cope with the new predator" [3].

“... his dominance and his faculties for upsetting so much of the rest of life serve to rule him out of what ${ }^{1}$ we think of as 'natural' relationships of living things" [2].

Corresponding author: Michael J. Vandeman, Ph.D., research fields: transportation, wildlife, and the impacts of transportation on wildlife. E-mail: mjvande@pacbell.net.
"To really come up with something new that's going to allow a species to live in a completely new environment takes a million years". Camille Parmesan.

Many answers have been given to this question, but none, to the author's knowledge, based on science. Even scientists, apparently, often avoid applying their knowledge when it may be inconvenient (e.g., interfere with our preferred lifestyle). For example, open any biology textbook and find where it defines "exotic species". Do you see any mention of the fact that humans are, throughout most of their range, an exotic species - or even a discussion of whether they are an exotic species? If biology is so valuable (which the author thinks it is), why do humans shy away from using it?

Another example: it is often claimed that humans are a natural part of the environment-humans are just an animal like any other animal. If that is true, then why aren't humans mentioned in the vast majority of natural histories? The fact is, humans consider themselves a part of the ecosystems when it's convenient (e.g. when 
humans want to justify recreation in wildlife habitat), and not, when it's not convenient (e.g. when choosing where to live: in a house!). When you die, will you re-enter the ecosystem just like any other dead organism? No! Humans are either cremated, or buried in a box, specifically to avoid the natural process of decay.

It is obvious that humans are a part of nature, or they couldn't touch and interact with it. The real question is Which part of nature are they?

Biology texts usually define an "exotic species" as one transported by humans to a new location, where it hadn't existed before. However, this is not a good definition, since the effect of the exotic species on its new surroundings has nothing to do with how it got there, but more to do with the fact that it is a newcomer. However, every species was new at some time in the past. So the question is, How long does it take to become a native species?

The author would like to suggest that a length of time that makes sense, biologically, is the time that it takes for the other species in the ecosystem to evolve (i.e., make persistent-"beneficial"-genetic changes) to adapt to the newcomer-say on the order of a million years. This would make humans (Homo sapiens) native only to (part of) Africa, and everywhere else, a relative newcomer-an exotic species. (This is not a value judgment, but simply a statement of biological fact).

Does this mean that humans should all move back to Africa? The author doesn't think so - it wouldn't help! Even in Africa, behavior changes so rapidly, on an evolutionary scale, that the only things that can evolve fast enough to keep up with humans are bacteria and viruses! So even in Africa, humans might as well consider themselves an exotic species.

But what the author does think it means is that humans should act with restraint — with the manners of a guest! What does this mean in practice? The author thinks it means, first of all, to "listen" to other species, and what they are trying to tell us! For example, what is the first thing that every child learns about wildlife?
That they don't want humans around: that they run away whenever humans try to approach them! And then, of course, because humans are the curious animals that they are, they proceed to ignore their wishes.

Jane Goodall, Dian Fossey, and Birute Galdikas all had the same experience when they began trying to study apes in the wild: the apes didn't want them around! They "told" the researchers that clearly and unequivocally. Jane couldn't get close to the chimpanzees until she started bribing them with bananas. The gorillas charged Dian and tried to scare her away. And the orangutans pushed over trees toward Birute, apparently trying to kill or intimidate her. The apes desperately need us to deliver their message to the rest of humanity. Although the message is impossible to miss, most humans ignore it. Rather than arguing over to what degree the apes resemble or differ from humans, the most important message that the author can derive from studying them is that they want to be left alone!

This is perhaps a bitter pill, but one that humanity urgently needs to take. With the population increasing rapidly, it is more important than ever to give wildlife what they want, which is also, therefore, what they need: freedom from the pressure, irritation, infection with diseases, and outright danger of the presence of humans. It is utterly inexcusable that humans continue extending our hegemony into every square inch of the Earth, and soon, other defenseless planets as well.

This is a tall order? Very well, then it is a tall order. But the author does not see why they shouldn't aim for what is needed, instead of pretending that less is adequate.

\section{References}

[1] Ehrlich, P. R., and Ehrlich, A. H. 1981. Extinction: The Causes and Consequences of the Disappearances of Species. New York: Random House.

[2] Errington, P. L. 1987. A Question of Values. Iowa: Iowa State University Press.

[3] Flannery, T. 2002. The Eternal Frontier: An Ecological History of North America and Its Peoples. New York: 
Grove Press.

[4] Foreman, D. 1991. Confessions of an Eco-Warrior. New York: Harmony Books.

[5] Knight, R. L., and Gutzwiller, K. J. 1995. Wildlife and Recreationists. Covelo, California: Island Press.

[6] Noss, R. F., and Cooperrider, A. Y. 1994. Saving Nature's Legacy: Protecting and Restoring Biodiversity. Covelo, California: Island Press.

[7] Stone, C. D. 1973. Should Trees Have Standing? Toward Legal Rights for Natural Objects. Los Altos, California: William Kaufmann, Inc.

[8] Vandeman, M. J., Accessed January 11,
$2015 . \quad$.http://mjvande.nfshost.com, especially http://mjvande.nfshost.com/ecocity3.htm, http://mjvande.nfshost.com/india3.htm, http://mjvande.nfshost.com/sc8.htm, and http://mjvande.nfshost.com/goodall.htm.

[9] Ward, P. D. 1994. The End of Evolution: On Mass Extinctions and the Preservation of Biodiversity. New York: Bantam Books.

[10] The Wildlands Project. 1994. Wild Earth. Richmond, Vermont: The Cenozoic Society.

[11] Wilson, E. O. 2002. The Future of Life. New York: Alfred A. Knopf. 